\title{
GAGASAN GERAKAN PSIKOLOGI ISLAM : SUATU PENDEKATAN PSIKOMETRIK
}

\author{
${ }^{1}$ Khaidzir Hj. Ismail, ${ }^{2}$ Khairil Anwar \\ ${ }^{1}$ Universiti Kebangsaan Malaysia \\ ${ }^{2}$ Program Pasca Sarjana UIN Sultan Syarif Kasim Riau \\ eying74@yahoo.com, izay@ukm.my
}

\begin{abstract}
In theory nor philosophy, psychology Islam has grown in line with the demands of the Islamization of knowledge. But to fight Islamic psychology as a discipline that is recognized, it is still far from reality. Resistance and these expectations requires a special epistemological paradigm and that led to the conceptualization and measurement (psychometric). In the context of history, a new psychology recognized as a science-based quantitative measurement verification, as expounded by William Wundt with strukturalismenya. Therefore this study tries to offer the concept of measurement in psychology Epistemology Islam by transformasik ideological, cultural and social development that is based on the Qur'an and the Hadith to form constructs and indicators of measurement are combined according to the existing psychometric methods. The concept as a form of mental-cognitive way of thinking is based on Islam has been built with special epistemological approach where measurement has been administered to Troubled Youth Rehabilitation Center In total 490 people. The results showed mental-cognitive level of these adolescents are at a low level. According to gender differences using the $\mathrm{t}$ test found women (mean $=248.81$ ) higher levels than men $(244,671)$ where $t=-2071$ with $p<0.05$. While in terms of reliability and validity indices showed fairly good. It is expected that the results of this study could have implications for the development of measurement tools and construction modules psychological intervention that is based on Islam.
\end{abstract}

Kata kunci : psikometrik, psikologi Islam dan mental-kognitif

\section{PENDAHULUAN}

Isu psikologi Islam yang begitu kuat gerakannya di kalangan ilmuan psikologi muslim, sebenarnya bukanlah semata-mata suatu dorongan untuk menolak konsepsi psikologi barat, namun ianya juga merupakan suatu kesedaran sejarah bahawa Islam telah lama 
Khaidzir Hj. Ismail ; Gagasan Gerakan Psikologi Islam : Suatu

Pendekatan Psikometrik

memilki khazanah pengkajian tentang kejiwaan manusia yang sangat inheren dengan keislaman itu sendiri. Secara historis "jiwa" telah mendapat tempat khusus yang penting untuk diperbincangkan di kalangan ilmuan Islam, khasnya di kalangan para ahli falsafah Islam, seperti Al-Kindi (801-866 M), ArRazi (864-925 M), Al-Farabi (872$950 \mathrm{M})$, Ibnu Miskawaih $1030 \mathrm{M})$, Ibnu Sina (980-1037 M), Ibnu Hazm (994-1064M), Al-Ghazali 1058-1111 M), Ibnu Bajah (1082-1138 M), Ibnu Thufail (1185 M), Ibnu Rushd (11261198 M), Fakhruddin Al-Razi (11501210 M), Ibnu Taimiyah (1263-1328 M), Ibnu Qayyim Al-Jauziyah (1292$1350 \mathrm{M}$ ) dan ahli falasafah Ikhwan ash-Shafa (Utsman Najati, 2002; Badi dan Tajdin, 2004)

Di samping perspekstif historis di atas, yang paling mendasar bagi gerakan psikologi Islam pada saat ini adalah terjadinya arus pemikiran Islamisasi ilmu. Isu islamisasi patut dijadikan sebuah momen penting untuk terus dikaji dan dikembang sebagai asas pengislaman fikiran umat Islam dari pengaruh peradaban moden yang serba sekular dan materialistik. Islamisasi mengikut takrifan Syed Naquib al Attas ialah suatu usaha terancang dan beransur-ansur yang akan membuahkan satu masyarakat yang berpegang teguh kepada keseluruhan ajaran Islam dalam semua aspek kehidupan masyarakat. (al Attas, dlm Wan Mohd. Nor Wan Daud, 1991). Selanjutnya dalam pandangan Wan Mohd. Nor Wan Daud (1991) al Attas lebih jauh telah merumuskan konsep islamisasi ilmu sebagai pembebasan dari tradisi tahayul, mitos, animis, kesukuan dan kebudayaan, serta pembebasan akal dan bahasa daripada pengaruh sekularisme. Dan bagi al Attas Islamisasi adalah proses dua hala; pembebasan diri (liberation) dan pengembalian diri (devolution) kepada kejadian asal yang fitrah. Untuk mencapai kesemua itu, bagi al Attas adalah langkah Islamisasi Akal dan pemikiran melalui Islamisasi Bahasa.

Diakui atau tidak, barat moden telah banyak mempengaruhi akal dan fikiran umat Islam. Paling tidak menurut al Attas (Lih. DIm Wan Mohd. Nor Wan Daud, 1991) roh dan peribadi kebudayaan dan tamaddun barat moden berteraskan oleh tiga factor utama:

1. Konsep dualisme yang menguasai pandangan mereka tentang realiti dan kebenaran. Konsep dualisme ini juga mewarnai berbagai-bagai aspek pemikiran dan kehidupan. Contohnya dualisme antara akal dan jasad, dan pemisahan antara kaedah rasionalisme dengan empirisme

2. Ajaran humanisme, iaitu jelmaan ideologi sekularisme yang memusatkan penilaian segala-galanya kepada fikiran manusia.

3. Konsep tragedi yang menyusup dalam setiap arena kehidupan baik falsafah, agama atau kesenian. Konsep ini mencerminkan jiwa tidak beriman kerana kecewa dengan agama. Konsep tragedi ini mengakibatkan mereka asyik berpandu kepada keraguan, dan dalam proses ini falsafah telah diiktiraf sebagai alat 
Al-Fikra: J urnal IImiah Keislaman, Vol. 16, No. 1, J anuari - J uni, 2017 (137 151 )

utama menuntut kebenaran yang tiada tercapai.

Dengan demikian islamisasi
ilmu tidak bermaksud proses
pengislaman ilmu itu sendiri, tetapi
merujuk kepada proses
pengislaman
tersebut (Nasr, 2008).
Tesis al Attas yang paling menarik adalah langkah Islamisasi ilmu harus dimulai dari Islamisasi Akal dan pemikiran melalui Islamisasi bahasa. Dari tesis beliau ini dicuba untuk menjawab kepada keperluan untuk proses islamisasi dalam bidang psikologi. Sebagaimana diketahui di dalam psikolgi sering berbicara masalah sikap (attitudes), personaliti (personalty) dan tingkah laku (behavior) (Lih. Ajzen, 2005), dan ketiga-tiga konsep ini tidak akan terlepas dari proses akal dan fikiran manusia. Akal dan fikiran manusia sangat besar pengaruhnya terhadap pembentukan sikap, personaliti dan tingkah laku manusia.

Kualiti akal dan fikiran manusia sangat menentukan cara berfikirnya terhadap suatu objek sama ada objek fizikal mahupun objek nonfizikal. Dalam kata lain apabila kualiti pembentuk cara berfikir seseorang dari sumber-sumber falsafah sekular-materilistik maka akan muncul sikap, personaliti dan tingkah laku yang sekularmaterialitik. Sebaliknya apabila yang yang memberi asas cara berfikir seseorang dari sumber spiritual-idealistik yang benar maka akan muncul pula sikap, personaliti dan tingkah laku yang benar, atau dalam bahasa Islam akan melahirkan diri al nafs al mutmainnah yang di dalamnya terkandung sikap, personaliti dan tingkah laku yang al taqwa, yang tentu dilahirkan dari sumber spiritual-idealistik yang Qur'ani (Khairil Anwar dan Khaidzir $\mathrm{Hj}$. Ismail, 2009).

\section{KONSEP PENGUKURAN PSIKOLOGI ISLAM}

Dalam sejarah perkembang ilmu psikologi, ilmu ini baru diakui sebagai cabang ilmu setelah ilmu ini dapat melalui uji kajian eksperimen kuantitatif yang terukur sebagaimana yang dipelopori William Wundt dengan strukturalismenya. Dengan kata lain ilmu ini memiliki asas penting iaitu dengan menggunakan kaedah pengukuran kuantitatif. Perkembangan psikologi begitu maju dengan pesatnya, di bawah kaedah kuantitatif ini. Beratus-ratus alat pengukuran psikologi yang telah dibina untuk dijadikan generalisasi teori dalam psikologi. Alat pengukuran ini juga dijadikan alat untuk mengenali sesebuah fenomena yang terjadi, sehingga dengan pengukuran dan segala bentuk hasil data yang diperoleh dari kaedah inilah dijadikan kesimpulan untuk mengambil polisi tertentu sama ada lembaga kerajaan mahupun swasta.

Pembinaan alat pengukuran di dalam psikologi adalah dibawah pembahasan sub cabang ilmu iaitu ilmu psikometrik. Salah satu unsur penting dalam psikometrik adalah persoalan konstruk pengukuran. Berbicara masalah konstruk inilah yang akan membawa suatu perbincangan yang stigmatic antara psikologi barat dan penerapannya dalam dunia Islam. Sebuah konsep 
Khaidzir Hj. Ismail ; Gagasan Gerakan Psikologi Islam : Suatu

Pendekatan Psikometrik

akan dioperasionalkan mengikut konstruk yang membentuknya. Dalam kata lain sesebuah konsep akan berbeza operasionalnya apabila dibentuk oleh konstruk yang berbeza, walaupun konsep yang dibahas adalah konsep yang sama. Konstruk dibentuk dari indikatorindikator khusus, yang akan dipengaruhi oleh ideology, budaya, sosial dan agama. Dengan dasar perbezaan konstruk inilah yang melahirkan cross culture psychology.

Dengan demikian isu yang terpenting dalam psikologi Islam di samping falsafah yang mendasari psikologi Islam adalah masalah pengukuran dalam psikologi Islam. Alasan kenapa isu ini menjadi penting adalah :

1. Berbicara masalah psikologi Islam haruslah dipertimbangkan

pembinaan pengukuran dalam psikologi Islam sebagai asas justifikasi psikologi Islam dapat digolongkan ke dalam ilmu psikologi.

2. Pembinaan pengukuran psikologi Islam adalah suatu keharusan untuk memasukkan konstrukkonstruk dan indikatorindikator yang bersumber dari budaya, sosial, ideologi dari sumber ajaran Islam ke dalam pengukuran konsep psikologi. Ertinya konsep personaliti, sikap dan tingkah laku harus diukur dari konstruk dan indikator yang bersumber dari keislaman.
3. Perlunya menambah konsep-konsep psikologi Islam dari konsepkonsep yang bersumber dari khazanah keislaman. Seperti perlu dibina alat pengukuran tentang konsep zuhud, shobar, tawakkal, wara' dan lain-lain seumpama itu. (Khairil anwar dan Khaidzir Hj. Ismail, 2009)

Stigma yang ironis dirasakan selama ini adalah pengukuran fenomena psikologi umat Islam selalu menggunakan pengukuran yang diambil dari barat. Padahal seperti yang telah dijelaskan di atas pengukuran tersebut adalah dibina dari konstruk dan indikator dari ideologi dan budaya barat. Logikanya apakah alat tersebut sesuai untuk mengukur suatu budaya masyarakat dengan alat ukur yang diambil dari budaya masyarakat lainnya?

Seperti contoh pengukuran kepuasan kerja dalam bidang kerjaya dan organisasi dalam masyarakat Islam, selalu menggunakan alat pengukuran job satisfaction atau job stress yang dibina oleh ilmuan barat. Padahal alat pengukuran ini setelah dianalisis, dibina berdasarkan teori Maslow yang materialis-humanistic, yang sangat tidak sesuai dengan ajaran dasar Islam.

Dalam teori Maslow, syarat utama diri yang dapat menentukan sistem menjadi baik adalah diri yang telah dipenuhi keperluankeperluan tertentu. Tokoh psikologi humanisme, Abraham Maslow, berteori bahawa manusia memiliki peringkat-peringkat keperluan yang harus dipenuhi secara liner. 
Al-Fikra: J urnal IImiah Keislaman, Vol. 16, No. 1, J anuari - J uni, 2017 (137 151 )

Peringkat keperluan manusia yang paling asas yang harus terpenuhi adalah keperluan sandang pangan (basic need). Sementara peringkat keperluan manusia yang tertinggi adalah aktualisasi diri (self ectulisation). Keperluan aktualisasi diri tidak akan pernah tercapai apabila keperluan asas tidak terpenuhi. Teori Maslow, banyak dianut dalam bidang pengurusan organisasi sebagai dasar untuk meningkatkan prestasi pekerja bagi mencapai produk tertentu. Maslow berkeyakinan bahawa sebesar apapun potensi kecerdasan manusia untuk sampai pada tahap aktualisasi diri, namun apabila pada tataran basic need-nya tidak terpenuhi, maka adalah suatu kegagalan yang fatal untuk membicarakan potensi manusia. Yang menjadi pertanyaan, mungkinkah manusia cerdas akan dikalahkan perjuangannya oleh ketidaktersediaan basic need? Sementara dalam banyak hal apakah tidak mungkin basic need harus disediakan oleh kecerdasan?

Dalam Islam, job satisfaction bukanlah berasaskan terpenuhinya keperluan-keperluan materialistic, namun lebih jauh ditentukan oleh amalan ibadah yang dilaksanakannya dan cara berfikirnya tentang suatu pekerjaan. Islam selalu menekankan kualiti seseorang selalu ditandai dengan iman dan amal soleh yang dilkukannya.

Maka pengukuran terhadap kes job satisfaction ini ada dua cara pendekatan psikologi Islam menenganinya :

1. Harus dibina pengukuran job satisfaction berdasarkan perspektif iman dan amal soleh, dan dari sinilah dibentuk konstruk dan indikator pengukuran job satisfaction.

2. Membina suatu alat pengukuran yang berbentuk self report (laporan kendiri) pengamalan ibadah sunat sehari-hari yang telah dilaksnakan.

Perlunya pengukuran ibadah sunnah yang dilakukan seseorang sebagai peramal dalam kupuasan kerja yang dialaminya, adalah suatu logika berfikir Islam, bahawa orang yang sentiasa menjaga amalan sunnat, mesti ringan melaksanakan ibadah wajib. Bahawa orang yang sentiasa menjaga amalan sunnat, akan terjaga keikhlasan hatinya, dan tentunya ia juga akan memberi pengaruh kepada minat, motivasi, prestasi, komitmen dan kepuasan kerja itu sendiri di lingkungan tempat individu tersebut bekerja, kerana ia mampu menjadikan segala aktiviti pekerjaannya sebahagian dari ibadah. Inilah psikologi Islam, yang berbeza sudut pandangnya dengan psikologi barat materialistik. Dalam tulisan ini telah dilampirkan satu set pengukuran sunnah yang dinamakan dengan Self Report of Sunnah Behavior (laporan kendiri sunnah). (Khaidzir Hj. Ismail dan Khairil Anwar, 2009)

\section{ME MB ANG UN REMAJ A DALAM PERSPEKTIF PSIKOLOGI ISLAM}

Dalam pembahasan psikologi Islam istilah-istilah penting yang selalu dibahasa adalah di sekitar istilah qalb, nafs, ruh dan 'aql. Ini adalah konsep-konsep penting yang menjadi dasar terbentuknya disiplin 
psikologi Islam. Dari segi keperluan falsafah dan teori telah banyak tulisan dan buku-buku yang membincangkan istilah dimaksud. Ertinya, dari perspektif islamisasi ilmu yang diketengahkan oleh al Attas, keperluan asas-asas falsafah islamisasi ilmu telah mencukupi. Bahkan apabila dirujuk falsafah Ibnu Sina dan Alfarabi tentang psikologi manusia terlihat lebih dalam analisisnya berbanding falsafah psikologi barat moden yang hanya setakat membicarakan manusia dalam konteks tingkah laku dan pemikiran yang tampak. Namun psikologi islam harus lebih jauh lagi melangkah dalam tataran aplikasi keilmuan yang dapat digunapakai.

Aplikasi keilmuan yang dapat diguna pakai adalah terealisasinya program program prevensi dan intervensi di kalangan umat Islam, khasnya di tengah remaja Islam. Remaja Islam hari ini tengah menghadapi badai moral dan spiritual yang menghendaki penyelesaian yang tepat dan cepat. Persoalan remaja adalah persoalan yang tidak boleh ditunda agak sedetik pun. Pada masa transisi keperibadian dan kognitif ini, mereka adalah kumpulan sosial yang paling mudah terserang oleh budaya materialis dan hedonis.

Selama masa remaja, individu mulai merasakan suatu perasaan tentang identitinya sendiri, perasaan bahawa ia adalah manusia unik, namun siap untuk memasuki suatu peranan yang berarti di tengah masyarakat, entah peranan ini bersifat menyesuaikan diri atau bersifat memperbaharui. Sang remaja mulai menyedari sifat-sifat yang melekat pada dirinya sendiri, seperti aneka kesukaan dan ketidaksukaannya, tujuan-tujuan yang dikejarnya di masa depan, kekuatan dan hasrat untuk mengawal nasibnya sendiri. Inilah masa dalam kehidupan ketika orang ingin menentukan "siapakah ia" pada saat sekarang dan ingin "menjadi apakah ia" di masa hadapan. Inilah masa untuk membuat rencana rencana kerjaya. Daya penggerak dalaman dalam rangka pembentukan identiti ialah ego dalam aspek-aspeknya yang sedar maupun tak sedar. Pada tahap ini ego memiliki kapasiti untuk memilih dan mengintegrasikan bakat-bakat, kemampuan kemampuan dan keterampilanketerampilan dalam melakukan identifikasi dengan orang yang sependapat dan dalam melakukan adaptasi dengan persekitaran sosial, serta menjaga pertahananpertahanannya terhadap berbagai ancaman dan kecemasan, kerana ia telah mampu memutuskan impuls-impuls, keperluan-keperluan dan peranan-peranan manakah yang paling sesuai dan efektif. Semua ciri yang dipilih ego ini dihimpun dan diintegrasikan oleh ego serta membentuk identiti dan psikososial seseorang.

Banyak kajian telah dijalankan untuk melihat fenomena remaja ini, jarang yang menyentuh titik kesedaran remaja, kebanyakan kajian baru ditingkat fenomena remaja yang ternampak. Seperti pengkajian tingkahlaku langsang remaja. Sebenarnya kajian yang terpenting adalah kajian yang menghubungkan remaja dengan suatu kesedaran yang mendalam tentang agamanya, dalam arti lain remaja harus dicerdaskan kognitif keagamaannya. 
Al-Fikra: J urnal IImiah Keislaman, Vol. 16, No. 1, J anuari - J uni, 2017 (137 151 )

Pentinganya pembicaraan mental-kognitif di kalangan remaja berisiko secara teoritikal dapat diterangkan bahawa tingkah laku individu sangat ditentukan oleh faktor kognitifnya (Andrade, 2004; Robertson, 2004; Kellog, 2003; Brunner, 1990; Baron, 1998, dalam Siti Hajar dan Abdul Hadi, 2009), maka diperlukan usaha untuk menterokai sejauh mana kesedaran remaja dan cara berfikirnya dalam kehidupan beragama. Kerana keberagamaan adalah titik sentral penting yang membezakan kualiti manusia bertingkahlaku. Selama ini yang tersentuh dalam aspek keagamaan di kalangan remaja baru pada tahap kognitif (pengetahaun) semata-mata. Dalam arti lain remaja hanya dikenalkan agama dalam satu sudut ilmu, dan tidak dikembangkan ke arah kesedarannya sebagai muslim yang kaaffah.

Permaslahan inilah yang membawa suatu hipotesis penting terjadinya kenakalan remaja atau remaja berisiko. Kerana disebabkan

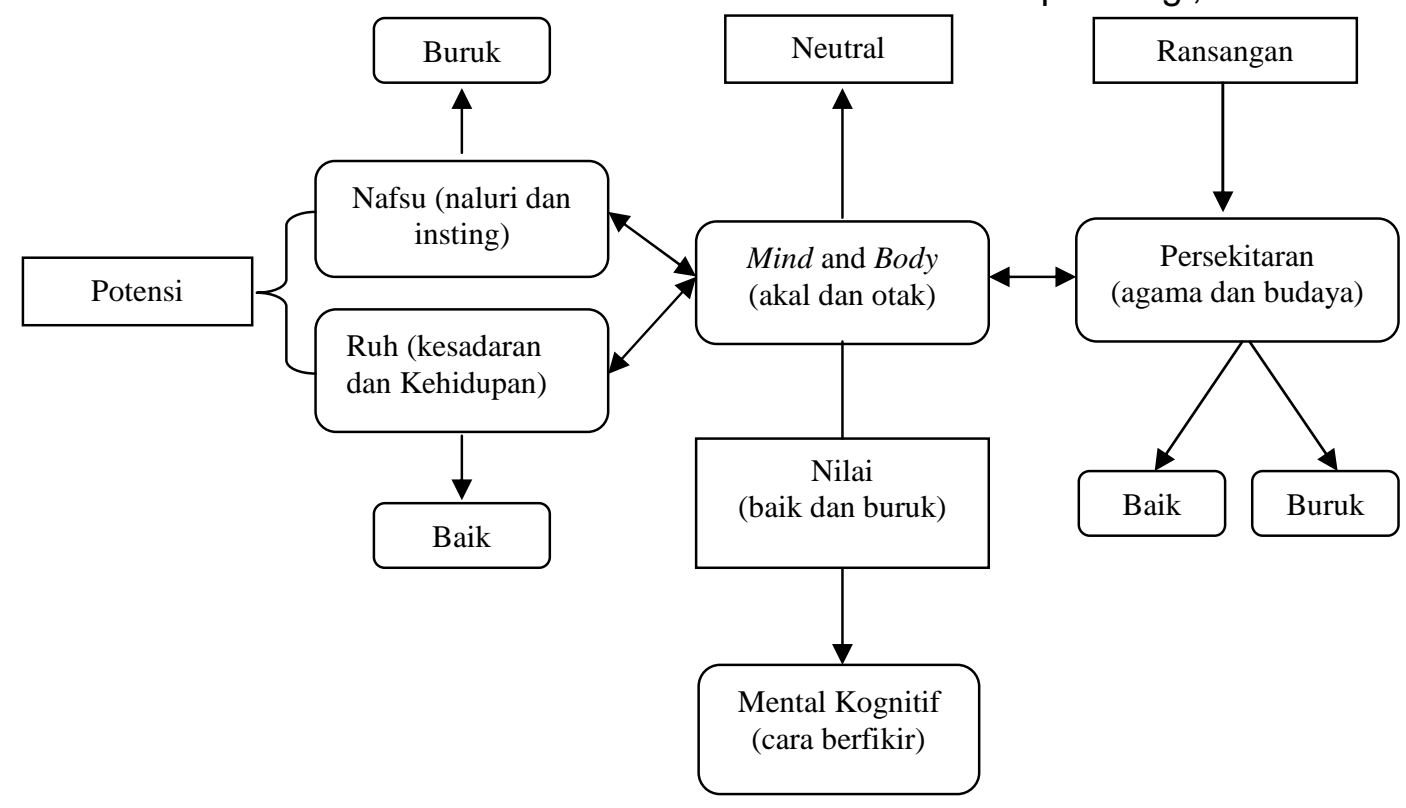

belum tersampaikannya suatu program pendidikan yang memberi iluminasi dan cara berfikir yang mendalam dan luas tentang sesuatu objek atau permasalahan yang dihadapi oleh remaja. Tentunya apa yang dimaksudkan oleh al Attas, yang paling penting adalah mengislamkan cara berfikir remaja Islam, sebagai pemangkin agama dan negara di masa hadapan.

\section{MODEL TEORITIKAL ME NTAL- KOGNITIF ISLAM}

Tesis al Attas yang mengawali permasalahan tulisan ini, yang menyangkut perlunya Islamisasi ilmu yang harus dimulai dari Islamisasi Akal dan pemikiran melalui Islamisasi bahasa, maka respon dari disiplin ilmu psikologi adalah diperlukan suatu pengkajian yang mendalam untuk melahirkan suatu sintesis yang dapat memberikan kontribusi terhadap islamisasi akal dan pemikiran. Dalam ilmu psikologi, akal dan

Gambar 1. Keranaka Teoritikal Mental-Koanitif dari Perspektif Islam 
fikiran serta bahasa adalah di bawah sub pengkajian psikologi kognitif. Istilah kognitif adalah merujuk kepada suatu proses kemampuan berfikir manusia untuk mengenali dan menenmukan maklumat sama ada yang bersumber dari dalaman manusia mahupun yang bersumber dari luaran manusia atau faktor persekitaran. Oleh itu pengkajian psikologi kognitif dalam perspektif psikologi Islam adalah salah satu usaha melakukan islamisasi akal dan fikiran, dan salah satu usaha yang dilakukan adalah dengan cara membina satu pengukuran yang mampu menggambarkan pola akal dan fikiran yang berteraskan Islam.

Untuk mengukur akal dan fikiran berteraskan islam, konsep yang cuba digunakan adalah Mental-Kognitif Islam, dan istilah mental-kognitif islam ini adalah bermakna cara berfikir berteraskan Islam. Adapun kerangka teoritikal mental-kognitif dari perspektif Islam (Khaidzir Hj.Ismail dan Khairil Anwar, 2009) adalah seperti gambar 1 di bawah ini :

Kerangka dasar ini memiliki bebarapa titik perberbezaan dengan konsep kognitif yang diketengahkan oleh konsep psikologi barat moden, perbezaannya terletak dari segi asas utama pembentuk kehidupan dan kesedaran manusia. Perbezaan mendasar tersebut adalah dinamakan dengan ruh. Membicarakan ruh tidak bererti ruh adalah objek yang dikaji dalam psikologi Islam, namun ruh adalah suatu elemen yang patut diyakini sebagai substansi dasar kehidupan dan kesedaran manusia. Pada prinsipnya ruh tidak dapat dikaji dan dieksperimen dengan pendekatan saintifik, kerana ia suatu realiti yang bersifat abstrak dan ghaib. Bahkan Allah dalam surat Banī Isrāīl (17) ayat 85 mengatakan ruh adalah urusanNya dan manusia hanya diberi sedikit ilmu tentang ruh.

Ruh adalah entiti yang memberikan kesedaran pada manusia untuk melakukan segala aktiviti, khasnya aktiviti berfikir. Ruh adalah potensi kehidupan manusia yang memiliki nilai kebenaran. Di samping ruh sebagai potensi kebaikan, dalam al Qur'an ada sebuah potensi kemauan (nafsu) yang juga mempengaruhi proses berfikir manusia yang lebih cenderung sebagai potensi kejahatan. Sebagaimana firman Allah dalam surah yusuf (13) ayat 53 bahawa nafsu tersebut menghampirkan manusia pada kejahatan.

Dua elemen inilah yang akan mempengaruhi cara berfikir manusia sama ada cara berfikir yang mendatangkan kebaikan atau cara yang tidak baik. Dari kerangka tersebut di atas dan apabila dihubungkan dengan fitrah, maka manusia akan bernilai baik bergantung apakah ruhnya yang memainkan peranan penting ataukah nafsuny. Apabila persekitaran seseorang individu berada dalam persekitaran yang baik maka ruh dapat diwarnai dengan kebaikan, kerana persekitaran yang baik akan menghalangi dominasi peranan nafsu dalam diri manusia.

Penyelidikan tentang fenomena ruh dan nafsu terbatas, maka untuk mengenalpasti keadaan dalaman seseorang dapat dikesan melalui kegiatan mental-kognitif seseorang. Apabila dalaman seseorang baik maka baiklah mental kognitifnya. IImu psikologi hanya sanggup 
Al-Fikra: J urnal IImiah Keislaman, Vol. 16, No. 1, J anuari - J uni, 2017 (137 151 )

singgah dalam ranah mentalkognitif sebagai objek kajian tentang manusia, kerana ia masih boleh diterangkan oleh beberapa simbol seperti pengetahuan, pemahaman dan pengamalan seseorang terhadap apa yang dia yakini. Dari kegiatan mental-kognitif inilah yang akan melahirkan sikap dan tingkah laku seseorang individu.

\section{DEFINISI KONSEP MENTAL- KOGNITIF ISLAM}

Dalam tahapan pembinaan pengukuran mental-kognitif Islam ini, telah disusun konstruk pengukuran yang terdiri dari 4 (empat) domain, yang masing masing domain memiliki konstrukkonstruk untuk selanjutnya di operasionalkan dalam bentuk indikator-indikator atau item-item pertanyaan yang bernada psikologi untuk mengenalpasti mental-kognitif islam seseorang individu atau masyarakat.

Adapun domain mental-kognitif terdiri dari : Pertama :llmu Ketauhidan yang dibentuk dari konstruk berikut : Arkanul iman, Hakikat yang pertama, Keesaan yang mutlak, Kesempurnaan tertinggi Qada dan kadar, Amal sendi keimanan, Iman dan dosa, Pertikaian, Nubuwah, Kekekalan atau keabadian, Tauhid merupakan tapak kebahagiaan, Tauhid merupakan tapak bagi akhlak yang mulia, Tauhid merupakan tapak bagi ketenangan jiwa dan batin, Tauhid membebaskan jiwa dari pengaruh kekuasaan orang lain, Tauhid menumbuhkan keyakinan tentang rezeki, Tauhid memberikan kehidupan yang baik, Hakikat syirik dan anasir-anasirnya dan Tauhid dan amar ma'ruf nahi munkar. Kedua : Hukum Islam Sumber hukum Islam, Arkanul Islam, Konsep Thoharoh, Konsep hukum, Konsep keadilan, Konsep syura, Konsep jama'ah, Konsep Jenayah, Konsep sahsiayah, Konsep muamalah, Konsep mu'asyarah, Islam dan hukum universal, Konsistensi dan flesibiliti hukum islam. Ketiga : Konsep Pengetahuan Islam : Al Qur'an dan ilmu pengetahuan, Hadis dan ilmu pengetahuan, Ekonomi islam, Pengurusan islam, Konsep kesihatan dan keselamatan islam, Sains islam, Modernisasi islam, Tokoh saintis islam, Kemajuan sains islam, Sains dan materialisma, Sains dan westernisma. Keempat: Sejarah Islam Falsafah sejarah, Sejarah dan kepentingan da'wah, Sejarah dalam al qur'an, Sejarah rasul Sejarah sahabat, Sejarah peradaban islam, Sejarah tokoh kontemporer islam, Sejarah konflik dalam islam.

\section{SIG NIFIKANSI KAJ IAN}

Diharapkan pembinaan pengukuran mental-kognitif Islam ini adalah suatu proses dialektika untuk terus mengembangkan dan menjayakan pengembangan disiplin mazhab ke lima psikologi islam dalam memberikan pengayaan terhadap psikologi islam dari sudut pandang psikometrik. Secepatnya para sarjana psikologi islam terus mengembangkan pengukuranpengukuran terhadap konsepkonsep yang bardasarkan keislaman. Dan diharapkan juga hasil kajian ini dapat dijadikan indeks mental-kognitif remaja Islam dari semasa ke semasa khasnya pada remaja muslim Malaysia. 
Khaidzir Hj. Ismail ; Gagasan Gerakan Psikologi Islam : Suatu

Pendekatan Psikometrik

Sehingga indeks ini dapat dijadikan suatu dasar untuk mengambil langkah-langkah prevensi dan intervensi demi kesejahteraan remaja untuk melanjutkan pembangunan negara Malaysia yang bertamaddun dalam dinamika masyarakat global hari ini.

Secara khusus pengukuran yang telah dihasilkan ini agar dapat dilanjutkan secara antarabangsa dan di diubahsuai ke dalam peringkat umur kanak-kanak, remaja dan dewasa.

\section{METODOLOGI KAJ IAN}

Reka bentuk kajian ini ialah kajian tinjauan (survey) dan kajian kepustakaan. Kajian tinjauan bermaksud, maklumat variabel kajian dikumpulkan dengan soal selidik yang diedarkan bagi tujuan mengetahui sejauh mana tahap variabel yang diukur pada sampel kajian. Dikatakan rekabentuk ini termasuk kajian kepustakaan kerana kajian ini bermula dari tinjauan teoritikal dan seterusnya teori dan konsep yang dianalisis dijadikan untuk membina soal selidik sebagai alat pengukuran kajian.

Populasi kajian ini adalah remaja yang sedang berada dalam pusat pemulihan yang disebabkan oleh tingkah salah laku yang melanggar aturan dan norma undang-undang. Ertinya popluasi kajian ini tidak membatasi pada jenis kesalahan yang dilakukan dan jenis pusat pemulihan yang sedang mereka ikuti.

Manakala persampelan kajian ini adalah berbentuk purposive random sampling, hal ini dimaksudkan sampel diambil hanya pada cluster umur remaja dan secara rawak diambil untuk dijadikan responden kajian. Telah diambil responden seramai 490 orang dari latar belakang demografi yang berbeza. Bagi responden kajian yang tidak pandai membaca, inumerator akan membantu membacakan soal selidik dimaksud tanpa menerangkan secara terinci maksud soal selidik, kerana keterangan yang panjang dari inumerator akan menyebabkan tidak mendapati data sebenar tahap variabel mental-kognitif Islam remaja yang akan diukur.

Lokasi kajian ini diambil dari empat negeri iaitu Terengganu, Kelantan, Melaka Dan Perak. Pemilihan lokasi ini berdasarkan keperluan untuk mengambil responden lelaki dan perempuan. Maka responden perempuan diambil pada pusat pemulihan terengganu dan kelantan, manakala responden lelaki diambil pada pusat pemulihan Perak dan Melaka.

Alat pengukuran kajian terdiri dari dua bahagian. Bahagian pertama adalah soalan yang menyangkut latar demografi responden seperti umur, jantina, pendidikan, pendidikan ibu/bapa, pekerjaan ibu/bapa, pendapatan ibu/bapa, asal, jenis kesalahan, tarikh masuk ke pusat pemulihan, bilangan adik beradik serta urutan kelahiran dan penjaga tempat tinggal sehari-hari remaja. Pemilihan latar demografi ini adalah berdasarkan keperluan untuk mencari lebih jauh fakor faktor yang dapat memberi kesan kepada terlibatnya mereka dengan tingkah salah laku. Bahagian kedua dalam alat pengukuran ini ada dua skala pengukuran iaitu skala Mentalkognitif Islam. 
Al-Fikra: J urnal IImiah Keislaman, Vol. 16, No. 1, J anuari - J uni, 2017 (137 151 )

$\begin{array}{ccc}\text { Tahap } & \text { mental-kognitif Islam } \\ \text { remaja } & \text { diukur dengan }\end{array}$ menggunakan skala binari iaitu jawapan ya dan tidak, dimana jawapan ya diberi nilai 2 dan jawapan tidak diberi nilai 1 . Skala ini terdiri dari soalan positif dan negatif. Apabila soalan negatif dijawap pada pilihan ya maka nilainya menjadi 1 dan sebaliknya bila memberi jawapan tidak akan diberi nilai 2. Skala ini memiliki 174 item terdiri dari 4 sub skala antara lain :

1. Sub skala ketauhidan dengan jumlah item pertanyaan sebanyak 21 item.

2. Sub skala hukum Islam terdiri dari 79 item.

3. Sub skala konsep pengetahuan 51 item

4. Sub skala Sejarah Islam 23 item

Berikut adalah contoh-contoh item mental-kognitif :

1. Mustahil kita beriman kepada yang ghaib kalau tidak ada bukti yang zahir

2. Tidak mengapa berbuat dosa semasa muda kerana boleh bertaubat kepada Allah di usia tua

3. Tidak perlu merasa bersalah apabila berbuat dosa kerana ia telah ditakdirkan Allah swt.

4. Pasti orang-orang beriman akan memperoleh harta dengan mudah dan banyak

5. Kita mesti benci dengan orang-orang yang tidak beriman

6. Banyak hukum-hakam Islam yang tidak sesuai lagi dengan perkembangan

zaman

7. Tidak selamanya yang haram itu dilarang dalam Islam, kerana ianya bergantung pada keperluan dan keinginan individu

8. Tidak mengapa mencampurkan sedikit yang haram ke dalam barang yang halal, asalkan tidak dalam jumlah yang banyak

9. Tidak adil menghina hubungan sesama jantina kerana mereka pun ada perasaan

10. Lebih khusyu' melaksanakan sholat fardhu sendirian di rumah

11. Pindah agama dibolehkan asalkan didorong oleh keinginan diri sendiri

12. Perkahwinan sesama jantina adalah prilaku semula jadi bagi sesetengah individu

13. Tidak salah mencuri jika tujuannya untuk melakukan kebajikan

14. Boleh berpelukan dan bercumbu asal tidak berzina

15. Berjudi dibolehkan jika tidak mendatangkan kemiskinan

16. Ibu bapa yang melakukan dosa besar tidak perlu ditegur kerana kita harus menjaga hatinya

17. Boleh menjual arak kepada orang bukan muslim

18. Pakar matematik tidak diharuskan mendalami ilmu tauhid kerana ia adalah bidang kajian ulama

19. Manusia boleh membelanjakan harta mengikut kepuasan diri, asalkan berpunca dari sumber yang halal 
Khaidzir Hj. Ismail ; Gagasan Gerakan Psikologi Islam : Suatu

Pendekatan Psikometrik

20. Pilihlah calon pemimpin yang kaya kerana kekayaan dapat membawa keadilan

21. Negara tidak akan maju apabila pemimpin terlalu banyak membicarakan tentang akhirat

22. Peraturan jalan raya tidak mengapa untuk dilanggar kerana ia bukan dari Allah

23. Islam lebih mengutamakan bidang fiqh berbanding bidang sains

24. Walaupun rumah dan pakaian kita tidak bersih, namun yang penting di hati kita ada iman kepada Allah

25. Lebih diutamakan membantu keperluan orang yang selalu menolong kita

\section{PENEMUAN DAN PERBINCANGAN}

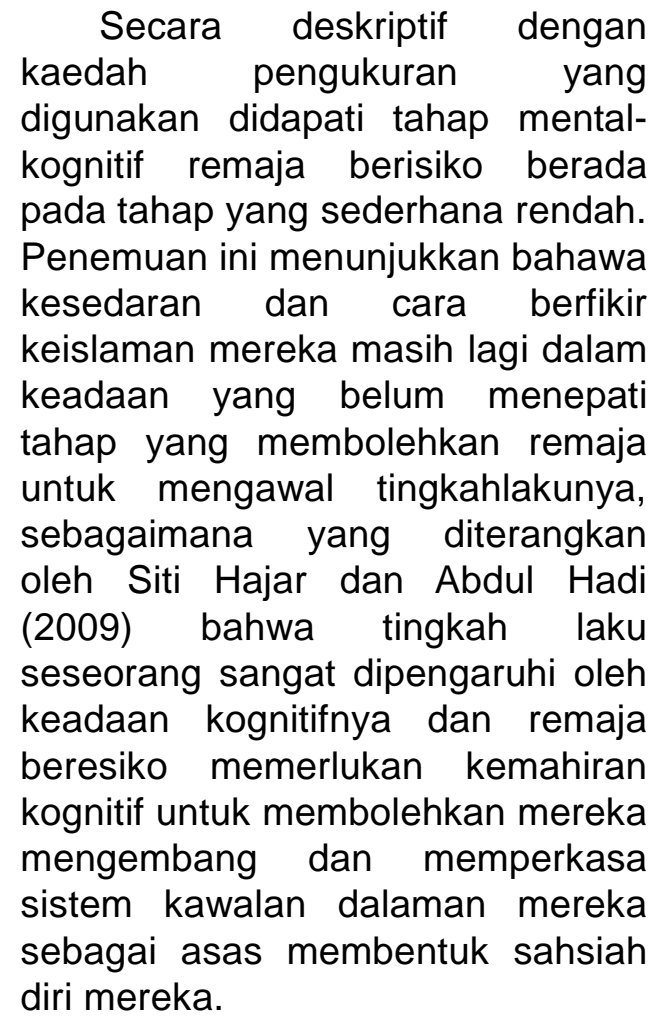

Secara deskriptif dengan digunakan didapati tahap mentalkognitif remaja berisiko berada pada tahap yang sederhana rendah. Penemuan ini menunjukkan bahawa kesedaran dan cara berfikir keislaman mereka masih lagi dalam keadaan yang belum menepati tahap yang membolehkan remaja untuk mengawal tingkahlakunya, sebagaimana yang diterangkan oleh Siti Hajar dan Abdul Hadi (2009) bahwa tingkah laku seseorang sangat dipengaruhi oleh keadaan kognitifnya dan remaja beresiko memerlukan kemahiran kognitif untuk membolehkan mereka mengembang dan memperkasa diri mereka.
Dalam perspektif psikologi perkembangan fenomena dapatan kajian ini adalah disebabkan remaja mengalami peralihan yang sukar dari masa kanak kanak ke masa dewasa, di satu pihak, dan kerana kepekaan terhadap perubahan sosial dan historis di pihak lain, maka selama tahap pembentukan identiti seorang remaja, mungkin merasakan penderitaan paling dalam dibandingkan pada masa masa lain akbat kekacauan peranan-peranan atau kekacauan Identiti. Keadaan ini dapat membuat individu merasa terasing, kesunyian, cemas dan bimbang. Remaja merasa bahawa ia harus membuat keputusan-keputusan penting, tetapi belum sanggup melakukannya. Para remaja mungkin merasa bahawa masyarakat memaksa mereka untuk membuat keputusan keputusan, sehingga justeru mereka semakin menentang. Mereka sangat peka terhadap cara orang-orang lain memandang mereka, dan menjadi mudah tersinggung dan merasa malu.

Selama kekacauan identiti, remaja mungkin merasa bahawa ia mundur dan bukan sebaliknya. Dan pada kenyataan kemunduruan untuk kembali bersikap dan berlaku pada sikap keanak-anakan di tengah tuntutan-tuntutan orang dewasa terhadap dirinya dalam peranannya di tengah masyarakat. Hal ini dilakukan untuk mencari suatu relaksasi dengan kembalinya ke alam kanak-kanak. Tingkah laku remaja tidak konsisten dan tidak dapat dijangka selama masa krisis ini. Pada suatu saat ia menutup diri terhadap siapapun kerana takut ditolak, dikecewakan, atau disesatkan. Pada saat berikutnya ia 
Al-Fikra: J urnal IImiah Keislaman, Vol. 16, No. 1, J anuari - J uni, 2017 (137 151 )

mungkin menjadi pengikut, pencinta, atau murid, dengan tidak menghiraukan akibat dari komitmennya itu.

Secara sosial keagamaan pula dan bersempena dengan ketauhidan sebagai teras utama dalam pengukuran ini, cara berfikir remaja sangat menentukan penilaian terhadap sesebuah objek atau permasalahan. Ketauhidan dalam arti sebenarnya adalah suatu kesedaran penuh mengetahui dan menghayati setiap unsur ajaran dalam agama Islam. Banyak hal dalam beragama manusia banyak yang mengetahui dan beramal dari luaran sahaja namun belum sampai kepada intipati sebuah ajaran agama.

Bercampurnya budaya materialisme dalam membangun ketamadunan adalah juga memberi pengaruh pada seseorang untuk memahami agamanya. Dalam bahawa hasil kajian mengenai cara berfikir dan bersosial remaja ini adalah sebuah potret kualiti sistem pendidikan yang masih jauh dari inti pati ajaran agama. Berkemungkinan besar pelajaran agama baru diajarkan pada tahap pengenalan dan pengetahuan tentang hukumhakam agama namun belum sampai kepada perubahan cara berfikir yang disertai dengan penghayatan yang akan meningkatkan amalan-amalan agama di kalangan remaja. (Khairil Anwar dan Khaidzir $\mathrm{Hj}$. Ismail, 2009).

Dalam kajian ini didapati juga perbezaan mental-kognitif mengikut perbezaan jantina, di mana dengan menggunakan ujian $t$ seperti dalam jadual 1 (satu) di bawah, tahap mental-kognitif lelaki ( $\min =244.68) \quad$ lebih rendah berbanding dengan perempuan ( $\mathrm{min}=248.89$ ) dimana nilai $\mathrm{t}=-2.071$ dengan $k<0.05$.

J adual 1. Perbezaan mental-kognitif mengikut jantina

\begin{tabular}{|l|l|l|l|l|l|l|}
\hline Pembolehubah & N & Min & SP & dk & t & P \\
\hline Lelaki & 256 & 244.68 & 20.66 & 453 & -2.071 & 0.039 \\
Perempuan & 193 & 248.89 & 21.70 & & & \\
\hline
\end{tabular}

$k<0.05$

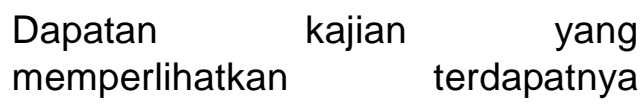
perbezaan mental-kognitif antara lelaki dan perempuan adalah sebuah indikasi bahawa remaja perempuan lebih memiliki kesedaran yang lebih mendalam berbanding dengan remaja lelaki. Memang secara psikoilogis perempuan lebih memiliki kecendrungan yang lebih tinggi dan lebih serius dalam proses pendidikan. Saat ini kebenyakan remaja yang cemerlang adalah dari kalangan perempuan. Tahap agresif pada lelaki yang lebih tinggi daripada perempuan, turut memberi kesan kepada tumpuan dalam memahami sesuatu objek ataupun permasalahan.

\section{PENUTUP}

Adalah satu kontinum yang pasti bahawa menyelasaikan sesuatu masalah perlu suatu 
Khaidzir Hj. Ismail ; Gagasan Gerakan Psikologi Islam : S uatu

Pendekatan Psikometrik

pendekatan yang sesuai untuk mendekatinya. Psikologi Islam tidak hanya diharapkan sebagai suatu gagasan dan gerakan islamisasi dalam ilmu psikologi, tapi lebih jauh adalah sebagai suatu alternatif penyelesaian masalah keadaan psiko-budaya umat Islam yang tengah terombang ambing di tengah badai globalisasi kebudayaan berfikir manusia yang cenderung kepada budaya hedonismaterilalistik. Tentunya yang paling perlu dipersiapkan adalah generasi pemangkin (baca;remaja) yang memiliki cara berfikir yang toleran dan filntrofis-egaliterianistik yang berpaksikan kepada al-Qur'an dan al-Hadis, dalam rangka membangun bangsa dan negara yang maju dan seimbang antara spiritual dan material.

Semoga dapatan kajian ini juga dapat menggesa ilmuan psikologi muslim untuk membina pengukuran-pengukuran dan modul prevensi dan intervensi yang berasaskan budaya kemelayuan dan keislaman.

\section{Daftar Pustaka}

Abdul Halim Ramli. (2007). Memahami Islamisasi Ilmu dari pemikiran Prof. Ismail Ragi AlFaruqi, Shah Alam: UiTm.

Ajzen, Icek. (2005). Attitudes, personality and behavior, England: Open Unversiti Press.

Al Attas, Syed Muhammad Naquib. (1995). Prolegomena to the metaphysics of Islam, an exposition of the fundamental elements of the worldview of Islam. Kuala Lumpur: ISTAC.

Al Faruqi, Ismail Ragi. (1991). Pengislaman ilmu, (Terj.).
Kuala Lumpur: Dewan Bahasa dan Pustaka.

Badri, Malik. (1980). Dilema ahli psikologi Islam : keadaan serba salah yang dihadapi oleh pakar ilmu jiwa Islam (dialihbahasa dan disunting oleh Fadlullah Wilmot), Petaling Jaya: FAWI.

Baharudin Ahmad. (2008). Falsafah sains dari perspektif Islam, Kuala Lumpur: Dewan Bahasa dan Pustaka.

Djamaluddin Ancok dan Fuat Nashori Suroso. (2008).Psikologi Islam; Solusi Islam atas problem-problem psikologi, Yogyakarta: Pustaka Pelajar.

Hidajat Nataatmajaya. (1983). membangun ilmu pengetahuan berlandaskan Ideologi (al bayyinah). Bandung: Iqra'.

Khaidzir Hj. Ismail dan Khairil Anwar. (2009). Pengukuran variable psikologi Islam: Pembinaan mental-kognitif Islam, Psikologi Islam : Falsafah, Teori dan Aplikasi, Kuala Lumpur: Institut Islam Hadhari \& iBook Publication.

Khaidzir Hj. Ismail et al (Ed.). (2009). Psikologi Islam : Falsafah, Teori dan Aplikasi, Kuala Lumpur: Institut Islam Hadhari \& IBook Publication.

Khairil Anwar dan Khaidzir Hj. Ismail. (2009). Profil Mental-Kognitif Dan Psiko-Sosial Islam Di Kalangan Remaja Beresiko, prosiding International Seminar of Islamic though,Bangi: UKM

Khairil Anwar dan Khaidzir Hj. Ismail. (2009). Tahap Mental-Kognitif Islam Dan Pengaruhnya Ke Atas Identiti Keagamaan Remaja Beresiko, Prosiding Persidangan Psikologi Malaysia 2009, Bangi: UKM. 
Al-Fikra: J urnal Ilmiah Keislaman, Vol. 16, No. 1, J anuari - J uni, 2017 (137 151 )

Mohd. Nasir Omar. (2005). Gagasan Islamisasi ilmu. Kuala Lumpur: Utusan publications \& distributions Sdn.Bhd.

Nik Aziz Nik Pa.(1999).Potensi Intelek, Selangor dar Ehsan: Dewan Bahasa dan Pustaka.

Osman Bakar. (1998). Classificationn of knowledge in Islam. Cambridge: The Islamic Texs Society.

Reed, Stephen K, (1999). Cognition ; Theory and aplication, USA: Thomson Learning.

Sa'fi, Louay. (1996). The foundation of knowledge, Petaling Jaya: IIUM

Sardar, Ziauddin. (2000). Merombak pola fakir intelektual muslim, Yogyakarta: Pustaka Pelajar.

Sarlito Wirawan Sarwono. (2006). Psikologi remaja, Jakarta: PT.Raja Grafindo Persada: Jakarta.

Siti Hajar Abu Bakar dan Abdul Hadi Zakaria. (2009). perlindungan kanak-kanak beresiko, Kuala Lumpur: Penerbit Universiti Malaya.

Thoyibi, $M$ dan Ngemron, $M$. (2001).Psikologi Islam, Surakarta: Muhammadiyah Press.

Wan Mohd. Nor Wan Daud. (1991). Penjelasan budaya ilmu. Kuala Lumpur: Dewan Bahasa dan Pustaka.

Wan Mohd. Nor Wan Daud. (1998). The concept of knowledge in Islam and its implications for education in developing country, London: Mansell Publishing Limited. 